\title{
Critical Factors Causing Material Wastes in Building Construction Projects
}

\author{
Shitaw Tafesse ${ }^{1 *}$ and Tamene Adugna ${ }^{2}$ \\ ${ }^{1}$ Department of Construction Technology and Management, College of \\ Engineering and Technology, Dilla University, PO Box 419, Dilla, Ethiopia \\ ${ }^{2}$ Faculty of Civil and Environmental Engineering, Jimma Institute of Technology, \\ Jimma University, Jimma, Ethiopia \\ *Corresponding author: shitu.taf@gmail.com
}

Published online: 15 December 2021

To cite this article: Shitaw Tafesse and Tamene Adugna (2021). Critical factors causing material wastes in building construction projects. Journal of Engineering Science, 17(2), 1-17, https://doi.org/10.21315/jes2021.17.2.1.

To link to this article: https://doi.org/10.21315/jes2021.17.2.1

\begin{abstract}
Construction sites generate a large amount of material wastes and have become a common problem with associated risks in Ethiopia. However, the sources of such wastes are not well recognised. Therefore, the purpose of this research was to analyse the risk factors that contribute to material wastes in building construction projects. To achieve this goal, the factors that cause construction wastes were identified from literature and construction experts via focus group discussions and personal interviews. Following this, the factors were subjected to a questionnaire survey to identify the most critical factors of construction wastes. The questionnaire was distributed purposively to 85 construction experts representing contractors, consultants, and clients and 70 questionnaires were duly received for analysis. The data were analysed with a mean score and ranked to identify the most critical factors generating material wastes at construction sites. According to the results of the study frequent changes made to the design, poor strategies for waste minimisation, improper storage of material, poor site management, poor planning and supervision, and errors of contract document were the most critical factors causing construction wastes.
\end{abstract}

Keywords: building construction, cause of waste, construction material, material waste

\section{INTRODUCTION}

The construction sector has been blamed for its environmental impact as it consumes large amounts of natural resources and contributes the largest portion of wastes. ${ }^{1}$ The rapid growth of this sector directly generates a huge quantity of 
construction waste. ${ }^{2}$ In the last century, the amount of construction waste generated from construction sites to landfill areas has increased. ${ }^{3,4}$ The increase in current construction activities in the world translated to a corresponding increase in the amount of wastes. ${ }^{5}$ This waste has resulted in serious and fatal impacts on urban sustainability and survival in terms of economic values and environmental safety. ${ }^{6}$ The enormous amounts of debris generated at construction sites lead to economic, social and environmental problems. ${ }^{7}$ At present, construction waste is the main barrier to sustainability and requires urgent solutions. ${ }^{8}$

Wastes from the construction site are the main causes of the health problem of the society and pollutants of the environment. In addition, it results in the reduction and depletion of natural resources as well as affects the sustainability of a construction project. According to Eze et al., ${ }^{9}$ material wastes generated from construction project site results in damage to the construction project, the environment and the economy. Environmental impact from material wastage includes soil contamination, water contamination and deterioration of landscape. ${ }^{10}$ Material wastage also has a negative economic impact by increasing project costs due to the need to replace and dispose of wasted materials. Enshassi, Al-Hallaq and Mohamed ${ }^{11}$ report that construction wastes are one of the major causes of building stakeholder's business failure in developing countries.

Various research results from different countries confirmed that construction material waste represents a relatively larger percentage of construction cost overrun. It is evident that waste is the major contributor to the construction project cost overrun and the total cost overrun due to material waste is $30 \%$ of the total cost of materials. ${ }^{9,10}$ Depending on the material type, $8.47 \%$ to $16.61 \%$ of the amount of material recorded as wastage from the total amount delivered to construction sites. ${ }^{12}$ The ranges of the percentage contribution of material waste to project-cost overrun is from $1.96 \%$ to $8.01 \%$, with an average contribution of $4.0 \%{ }^{13}$ This and other impacts from construction wastes, therefore, need to be managed properly to achieve sustainable construction. However, to develop and implement waste management strategies, nature and its source must be identified. In Ethiopia, the rate of construction has increased along with the increasing amount of waste generated from time to time. ${ }^{14}$ This situation has initiated the identification of the root causes and the development of key waste management strategies for preventing and reducing the stream of wastes..$^{15}$

The identification of the sources of wastes and the corresponding ranking will help prioritise the problems as well as develop and implement mitigation strategies for waste reduction and effectiveness. ${ }^{10}$ Waste reduction has many benefits, including conservation of natural resources and reduction in the use of 
virgin materials to produce construction materials, cost reductions from reducing the number of construction materials and reducing expenses from waste disposal. ${ }^{16}$ Other benefits from waste reduction include decreasing carbon dioxide emissions $\left(\mathrm{CO}_{2}\right)$, reducing health problems in workers and communities around construction sites, prolonging landfill life spans and reducing the cost of projects. ${ }^{17}$ Therefore, the purpose of this research was to examine the critical factors that contribute to material wastes in building construction projects in Addis Ababa, Ethiopia. The outcome will serve as a reference for construction experts and researchers by providing the critical factors causing construction wastes in the area. This will be significant in developing and implementing appropriate waste mitigation measures based on their sources. Such measures will subsequently help lower high project costs due to material wastes, safeguard material resources and improve the sustainability of the building construction sector.

\subsection{Causes of Construction Wastes}

Material waste can originate from different sources in the construction sites. Researchers have identified the factors causing material wastes. A study by Ghanim ${ }^{18}$ classified the root causes of material wastage into six major groups: design and contract documents, site management, procurements, storage and handling of materials, workers and supervision, site conditions and external factor. Ikau, Joseph and Tawi ${ }^{19}$ identified the major sources of material wastage as design, procurement, material handling and construction stage. Some of the major causes of construction wastes are lack of adequate documentation, poor communication, negligence and changes to specifications among others. ${ }^{20}$ Kaliannan et al. ${ }^{2}$ analysed the root causes of construction waste generation and categorised them into design and document, project management, material and equipment, human resources, project site condition and other external. Design and contract documents, procurement, handling, storage, workers, site management and supervision and external factors were presented as the main sources of wastes at construction sites with each group having several factors. ${ }^{21}$

Waste can be because of rework contrary to drawings and specifications, design changes and revisions and waste from uneconomical shapes. ${ }^{8}$ According to Olusanjo, Panos and Ezekiel ${ }^{10}$ the factors that influence the generation of material wastage are data error, design, handling, operation, weather, vandalism, misplacement, residual and others. The major factors that lead to the generation of material wastage are design and documentation, operational, procurement, materials storage and handling factors. ${ }^{22}$ Sasidharani and Jayanthi ${ }^{23}$ also identified the major sources of material wastage as material handling, site management, operational, procurement and design and documentation attributes. In addition, 
as described in the literature, the causes of waste during the design phase include design changes, design and detailing errors, material specification, design and detailing complexity and ineffective communication and coordination among the design team. ${ }^{24,25}$ In general, previous research are evident that the natures or sources of wastes vary from country to country and even from site to site due to the performance of the sector, method of construction, coordination between stakeholders, awareness of the sectors regarding the impacts associated with construction wastes, the management strategies of the sectors and other factors.

\section{METHODS}

The current study was developed to identify the critical factors contributing to construction wastes. The next section provides a methodological approach of this study including the data sourcing, collection and analysis process of the study.

\subsection{Research Instrument}

At the early stages of this study, observation of building construction sites and an interview with selected construction experts were conducted. To explore qualitative data, in-depth interviews with the individual or multiple participants could be employed. ${ }^{26}$ This was followed by a comprehensive review of literature on the significant factors causing construction wastes. Forty-seven factors causing construction wastes were identified and the factors that have similar nature were categorised into eight main groups. Then, a questionnaire was designed and prepared to send to construction experts. A questionnaire helps to cheaply reach out to large audiences, through a standardised means of data collection, thereby helping generalisability of the research findings, ${ }^{26}$ a questionnaire is a systematic compilation of questions that are submitted to a sampling of the population from which information is desired. ${ }^{27}$

The validity of the contents and appropriateness of the questionnaire were checked by construction experts. A pilot survey was conducted to test the reliability of the contents and the design of the questionnaire. A potential threat to the questionnaire survey, regarding content validity, can be addressed by a comprehensive literature review, while it ensured face validity through a pilot study. ${ }^{28}$ The pilot study provided an additional opportunity for asking the respondents about other sources of material wastes and the feedback was used to improve the limitation of the questionnaire. Finally, the improved questionnaire served as a means of data collection was distributed to 85 stakeholders (contractors, consultants and clients) on their project site and head office using purposive 
sampling. The selection criteria of the study respondents were based on their job position, experience, availability and convenience to participate in the survey. Out of the distributed questionnaire, 70 were duly returned for analysis, representing a high response rate of $81.67 \%$.

\subsection{Data Analysis}

The collected data from the targeted respondents were analysed with the descriptive statistics method (mean score) on Microsoft Excel version 2016. A 5-point Likert scale, ranging from 1 (Very low influence) to 5 (Very high influence) was adopted to address the agreement level of the respondents and to calculate the mean result for each factor that contribute to material wastes. Given the nature of ordinal scales, the numbers assigned to degree of influence (e.g., 1, 2, 3, 4 and 5) do not indicate that the interval between scales is equal nor do they indicate absolute quantities, rather they are merely numerical labels. ${ }^{11}$ The Likert scales used were 1 = "Very low influence", 2 = "Low influence", 3 = "Moderate influence", 4 = "High influence" and $5=$ "Very high influence".

\section{RESULTS}

\subsection{Ranking the Causes of Material Wastes}

Table 1 shows the 47 factors causing material wastes, the major category level of each factor, the number of responses for each ordinal scale, the mean value and the ranks by category and the overall ranks of all factors.

Table 1: Mean and rank of construction waste causes.

\begin{tabular}{|c|c|c|c|c|c|c|c|c|c|}
\hline \multirow{2}{*}{$\begin{array}{l}\text { Factor } \\
\text { level }\end{array}$} & \multirow[t]{2}{*}{ Factors } & \multicolumn{5}{|c|}{$\begin{array}{l}\text { Number of respondents } \\
\text { scoring }\end{array}$} & \multirow[t]{2}{*}{ Mean } & \multirow{2}{*}{$\begin{array}{l}\text { Rank by } \\
\text { Category }\end{array}$} & \multirow{2}{*}{$\begin{array}{l}\text { Overall } \\
\text { Rank }\end{array}$} \\
\hline & & 1 & 2 & 3 & 4 & 5 & & & \\
\hline DDF1 & Frequent changes of design & - & - & - & 25 & 45 & 4.65 & 1 & 1 \\
\hline PMF1 & $\begin{array}{l}\text { Poor strategy of waste } \\
\text { minimisation }\end{array}$ & - & 1 & - & 24 & 45 & 4.62 & 1 & 2 \\
\hline MSF1 & $\begin{array}{l}\text { Improper storage of } \\
\text { material }\end{array}$ & 1 & 1 & - & 21 & 47 & 4.60 & 1 & 3 \\
\hline PMF2 & Poor site management & - & - & 2 & 25 & 43 & 4.59 & 2 & 4 \\
\hline PMF3 & $\begin{array}{l}\text { Poor planning and } \\
\text { supervision }\end{array}$ & - & 2 & 2 & 20 & 46 & 4.57 & 3 & 5 \\
\hline
\end{tabular}


Table 1 (continued)

\begin{tabular}{|c|c|c|c|c|c|c|c|c|c|}
\hline \multirow{2}{*}{$\begin{array}{l}\text { Factor } \\
\text { level }\end{array}$} & \multirow[t]{2}{*}{ Factors } & \multicolumn{5}{|c|}{$\begin{array}{l}\text { Number of respondents } \\
\text { scoring }\end{array}$} & \multirow[t]{2}{*}{ Mean } & \multirow{2}{*}{$\begin{array}{l}\text { Rank by } \\
\text { Category }\end{array}$} & \multirow{2}{*}{$\begin{array}{l}\text { Overall } \\
\text { Rank }\end{array}$} \\
\hline & & 1 & 2 & 3 & 4 & 5 & & & \\
\hline DDF2 & Error in contract document & - & - & 5 & 21 & 44 & 4.56 & 2 & 6 \\
\hline WF1 & $\begin{array}{l}\text { Rework due to workers } \\
\text { mistake }\end{array}$ & 1 & 2 & 2 & 27 & 38 & 4.42 & 1 & 7 \\
\hline PMF4 & $\begin{array}{l}\text { Inappropriate construction } \\
\text { methods }\end{array}$ & 1 & 3 & 1 & 27 & 38 & 4.40 & 4 & 8 \\
\hline DDF3 & Irregular shape of design & 3 & 3 & 1 & 22 & 41 & 4.36 & 3 & 9 \\
\hline WF2 & $\begin{array}{l}\text { Lack of specialise } \\
\text { professional }\end{array}$ & 2 & 1 & 4 & 27 & 36 & 4.35 & 2 & 10 \\
\hline WF3 & Shortage of skilled workers & 2 & 1 & 4 & 28 & 35 & 4.33 & 3 & 11 \\
\hline PMF5 & $\begin{array}{l}\text { Lack of co-ordination } \\
\text { among parties }\end{array}$ & - & - & 9 & 30 & 31 & 4.32 & 5 & 12 \\
\hline PMF6 & $\begin{array}{l}\text { Using inappropriate } \\
\text { equipment and tools }\end{array}$ & 2 & 2 & - & 35 & 31 & 4.30 & 6 & 13 \\
\hline PMF7 & $\begin{array}{l}\text { Lack of environmental } \\
\text { awareness }\end{array}$ & 1 & 1 & 7 & 29 & 32 & 4.29 & 7 & 14 \\
\hline DDF4 & $\begin{array}{l}\text { Specifying material and } \\
\text { member size without } \\
\text { considering waste }\end{array}$ & - & 7 & 8 & 14 & 41 & 4.27 & 4 & 15 \\
\hline DDF5 & $\begin{array}{l}\text { Designing without } \\
\text { considering standard } \\
\text { material dimension }\end{array}$ & 5 & 3 & 5 & 13 & 44 & 4.26 & 5 & 16 \\
\hline PMF8 & $\begin{array}{l}\text { Low awareness of } \\
\text { recycling wastes }\end{array}$ & 6 & 2 & 3 & 17 & 42 & 4.25 & 8 & 17 \\
\hline PMF9 & Delay of payment & 5 & 3 & 4 & 17 & 41 & 4.23 & 9 & 18 \\
\hline DDF6 & $\begin{array}{l}\text { Mistakes in quantity survey } \\
\text { and specification }\end{array}$ & 6 & 1 & 7 & 14 & 42 & 4.22 & 6 & 19 \\
\hline WF4 & $\begin{array}{l}\text { Incompetent consultants } \\
\text { engineer }\end{array}$ & - & - & 16 & 24 & 30 & 4.20 & 4 & 20 \\
\hline MSF2 & $\begin{array}{l}\text { Damage during } \\
\text { transportation }\end{array}$ & 5 & 2 & 8 & 15 & 40 & 4.19 & 2 & 21 \\
\hline MSF3 & Poor packaging & 8 & 1 & - & 23 & 38 & 4.17 & 3 & 22 \\
\hline DDF7 & Poor design quality & 4 & 5 & 7 & 14 & 40 & 4.16 & 7 & 23 \\
\hline PF1 & $\begin{array}{l}\text { Purchase of materials } \\
\text { contrary to specification }\end{array}$ & 2 & 2 & 6 & 34 & 26 & 4.15 & 1 & 24 \\
\hline $\mathrm{EF} 1$ & $\begin{array}{l}\text { Lack of legislative } \\
\text { enforcement }\end{array}$ & - & 3 & 12 & 28 & 27 & 4.13 & 1 & 25 \\
\hline MSF4 & $\begin{array}{l}\text { Wrong handling of } \\
\text { materials }\end{array}$ & - & 5 & 11 & 26 & 28 & 4.10 & 4 & 26 \\
\hline
\end{tabular}


Table 1 (continued)

\begin{tabular}{|c|c|c|c|c|c|c|c|c|c|}
\hline \multirow[t]{2}{*}{$\begin{array}{l}\text { Factor } \\
\text { level }\end{array}$} & \multirow[t]{2}{*}{ Factors } & \multicolumn{5}{|c|}{$\begin{array}{l}\text { Number of respondents } \\
\text { scoring }\end{array}$} & \multirow[t]{2}{*}{ Mean } & \multirow[t]{2}{*}{$\begin{array}{l}\text { Rank by } \\
\text { Category }\end{array}$} & \multirow{2}{*}{$\begin{array}{l}\text { Overall } \\
\text { Rank }\end{array}$} \\
\hline & & 1 & 2 & 3 & 4 & 5 & & & \\
\hline TF1 & $\begin{array}{l}\text { Lack of recycling } \\
\text { technology }\end{array}$ & 6 & - & 9 & 22 & 33 & 4.09 & 1 & 27 \\
\hline TF2 & $\begin{array}{l}\text { Lack of latest technology } \\
\text { product }\end{array}$ & 6 & 3 & 8 & 16 & 37 & 4.07 & 2 & 28 \\
\hline TF3 & $\begin{array}{l}\text { Poor technology or } \\
\text { malfunction of equipment }\end{array}$ & 8 & 2 & 9 & 12 & 39 & 4.03 & 3 & 29 \\
\hline PF2 & Ordering errors & 8 & 3 & 8 & 12 & 39 & 4.02 & 2 & 30 \\
\hline PMF10 & Leftover material on site & 6 & 6 & 6 & 16 & 36 & 4.00 & 10 & 31 \\
\hline DDF8 & Slow drawing distribution & 2 & 9 & 10 & 16 & 33 & 3.99 & 8 & 32 \\
\hline PMF11 & Insufficient instructions & 3 & 7 & 13 & 13 & 34 & 3.97 & 11 & 33 \\
\hline EF2 & $\begin{array}{l}\text { Change of government } \\
\text { regulations }\end{array}$ & 5 & 6 & 10 & 16 & 33 & 3.95 & 2 & 34 \\
\hline $\mathrm{TF} 4$ & Change in technology & 10 & 5 & - & 20 & 35 & 3.93 & 4 & 35 \\
\hline DDF9 & $\begin{array}{l}\text { Complex detailing of } \\
\text { drawing }\end{array}$ & 4 & 5 & 15 & 16 & 30 & 3.90 & 9 & 36 \\
\hline DDF10 & Long project duration & 8 & 4 & 11 & 21 & 26 & 3.76 & 10 & 37 \\
\hline SCF1 & $\begin{array}{l}\text { Effects of subsurface } \\
\text { conditions }\end{array}$ & 8 & 7 & 6 & 22 & 27 & 3.76 & 1 & 38 \\
\hline EF3 & Theft and vandalism & 11 & 3 & 3 & 29 & 24 & 3.75 & 3 & 39 \\
\hline EF4 & Effect of weather & 2 & - & 27 & 31 & 10 & 3.67 & 4 & 40 \\
\hline $\mathrm{SCF} 2$ & Poor site layout & 10 & 4 & 8 & 26 & 22 & 3.66 & 2 & 41 \\
\hline EF5 & Defect of material producer & 4 & 17 & 12 & 4 & 33 & 3.65 & 5 & 42 \\
\hline PF3 & Suppliers' error & 6 & 12 & 14 & 8 & 30 & 3.63 & 3 & 43 \\
\hline PF4 & $\begin{array}{l}\text { Requirements to bulk } \\
\text { purchase }\end{array}$ & 8 & 9 & 9 & 20 & 24 & 3.62 & 4 & 44 \\
\hline SCF3 & Congestion of the site & 8 & 9 & 14 & 20 & 19 & 3.47 & 3 & 45 \\
\hline SCF4 & $\begin{array}{l}\text { In-sufficient space for } \\
\text { movement }\end{array}$ & 4 & 12 & 16 & 27 & 11 & 3.42 & 4 & 46 \\
\hline SCF5 & Unforeseen problems & 3 & 14 & 29 & 6 & 18 & 3.32 & 5 & 47 \\
\hline
\end{tabular}

Notes: $\mathrm{DDF}=$ Design and document factors; $\mathrm{PMF}=$ Planning and management factors; $\mathrm{MSF}=$ Material handling and storage factors; $\mathrm{PF}=$ Procurement factors; $\mathrm{WF}=$ Worker factors; $\mathrm{TF}=$ Technology factors; $\mathrm{SCF}=\mathrm{Site}$ condition factors; $\mathrm{EF}=$ External factors. 


\subsubsection{Design and Document Factors}

Errors that lead to construction wastes have started at the planning and designing stages of the projects in addition to the construction level of the projects. The mean and rank of 10 factors grouped under Design and document factors are shown in Table 1. Frequent changes of design, errors in contract documents and irregular shape of the design were the three top-ranked factors causing construction wastes. The lowest-ranked Design and document factors factors that contribute to material wastes were complex detailing of drawing and long project duration with a mean value of 3.90 and 3.76 , respectively.

\subsubsection{Planning and Management Factors}

The mean score ranks of the factors by category and the overall ranks of 11 factors grouped under Planning and management factors are presented in Table 1. The result indicated that poor strategy of waste minimisation, poor site management, inappropriate plans and site supervision were the three critical factors that lead to building construction wastes. This implies that effective management has a major role in achieving waste-effective construction sites. The output of the project depends on the plan and the management system adopted.

\subsubsection{Material Handling and Storage Factors}

Construction material deteriorates and damage due to inadequate storage and handling. Table 1 represents the mean score and the ranks of four factors contributing to construction wastes categorise under Material handling and storage factors. The result shows that improper storage of material was the first critical factor that causes material waste in Addis Ababa building construction projects with a mean score of 4.60. Besides, damage during transportation and poor packaging held the second and third ranks as a cause of construction wastes with a mean value of 4.19 and 4.17. Wrong handling of materials takes the lowest order compared to other Material handling and storage factors causing material wastes with a mean result of 4.10 .

\subsubsection{Procurement Factors}

In a construction project, an adequate procurement system is required to have the right material with the right quantity at the right time. The influential factors that are categorised under Procurement factors and contributed to the generation of material wastes include purchase of material contrary to specification, ordering error, the requirement for bulk purchase, supplier's error and non-involvement as shown in 
Table 1. From the analysis result, purchase of material contrary to the specification $($ mean $=4.02)$ ranked as the most critical factor that causes construction wastes. Ordering error took the second position as a source of material wastage with a mean value of 4.02. In contrast, supplier error was the third contributor to construction wastes with a mean score of 3.63. Although the requirement for the bulk purchase (mean $=3.62$ ) was held the least rank as a contributor of construction material wastes.

\subsubsection{Worker Factors}

There are a number of professionals in building construction sites, skilled or nonskilled and the role they play in this sector is significant for the achievement of projects performance requirements. Construction workers have their contribution to the quantity of wastes generated from construction sites. The mean value ranks of the factor by category and the overall ranks of the four factors that are grouped under Worker factors are presented in Table 1. It is depicted that lack of specialised professionals with a mean value of 4.35 was the highest critical factor causing material wastes, whereas shortage of skilled workers followed by a mean value of 4.33 and incompetent consultant engineer is ranked as the third contributor for the generation of construction wastes at building construction projects of Addis Ababa, Ethiopia.

\subsubsection{Technology Factors}

Technology and its product play a key role in the construction industry, and it includes all the products of technology (building components, plants, equipments and others). It is a barrier and not widely adopted in the Ethiopian construction sector and most of the building projects followed the traditional construction system and are labour-intensive. The total number of responses for each Likert scale, mean value and the ranks of the four factors that are categorised under Technology factors are depicted in Table 1. The analysis result indicated that lack of recycling technology ranked as the most contributing factor for construction wastes and a large amount of materials are leftover on the project site and dumped to landfill sites. Lack of emerging technology products found to be the second cause factor and poor technology or malfunction of equipment was the third risk factor contributing to construction wastes. 


\subsubsection{Site Condition Factors}

Table 1 depicts the number of respondent's responses on each factor contributing to the occurrence of wastes that are grouped under Site condition factors and their rank order done based on the mean results. The effects of subsurface conditions took the first rank in its effect to cause material wastage. Poor site layout was also ranked as the second critical factor leading to construction material wastes while congestion on the site is the third-ranked factor causing material wastage over the other causative factors.

\subsubsection{External Factors}

The mean and ranks of the five factors that are grouped under the External factors are presented in Table 1. The result has indicated that lack of legislative enforcement $($ mean $=4.13)$ was the highest contributor of wastes. Change of government regulations $($ mean $=3.9)$ ranked second in its event among all the examined factors, which demonstrates the essential impact on construction waste generation. Theft and vandalism ranked as the third out of five factors in this category that have a critical impact on construction waste generation. Effect of weather and defects of material producer took the least fourth and fifth position.

\subsection{Critical Factors Causing Material Wastes}

Analysing many factors is not effective and the sector should be concentrated on handling the main problems confronting the building sectors. Pareto principle (80/20 rule) states that for many events roughly $80 \%$ of the effect comes from $20 \%$ of causal factors. Based on this principle the concerned body should especially focus on the top 10 or $20 \%$ critical factors out of the 47 factors explored in this study. Figure 1 outlines the top ten critical factors causing construction wastes based on their overall ranks and category. 


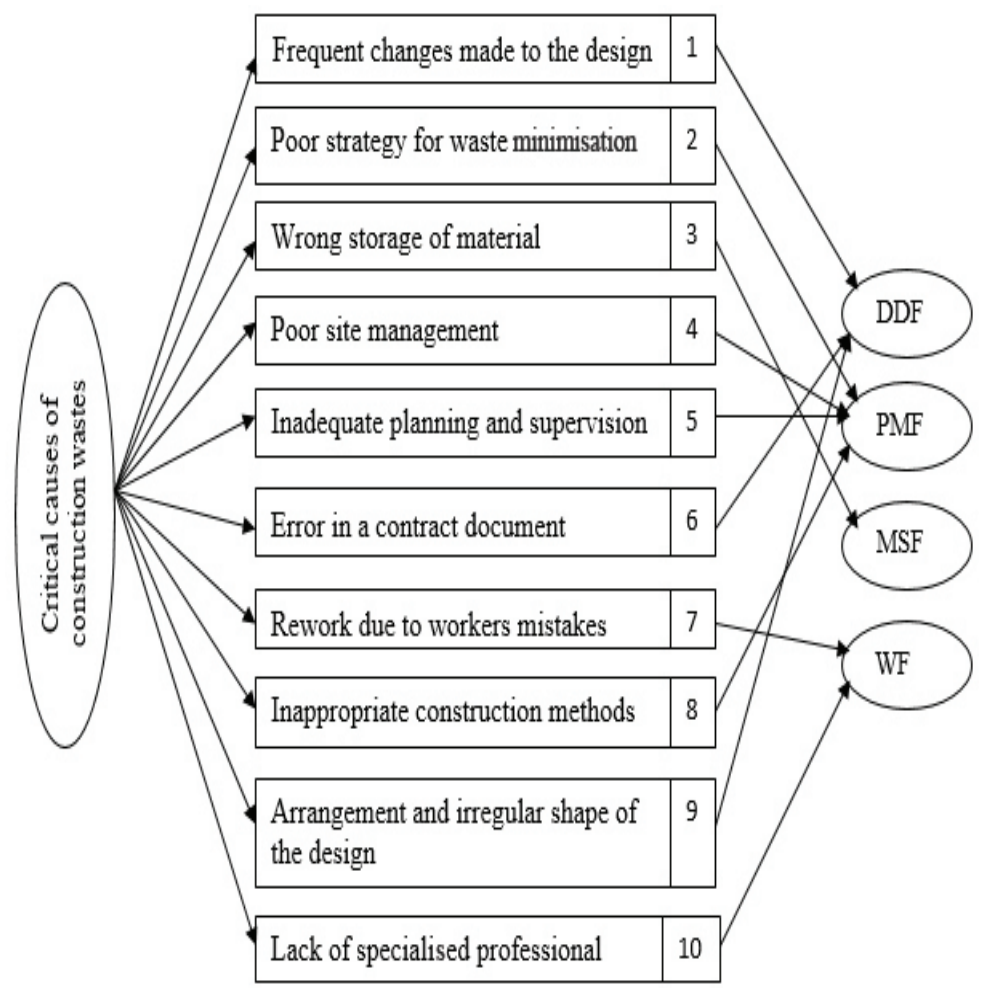

Figure 1: Critical factors causing construction wastes.

\section{DISCUSSIONS}

The result of this study reported that frequent changes of the design while construction is in progress are critical factors causing construction wastes. For example, if the required material is purchased based on the original design and the design is changed while the work is in progress, material wastage will occur if the material cannot be resold or returned to the source or supplier. In addition, design change is made when the project is in progress, demolishing and rework is required which leads to wastage. Design changes while construction is in progress are the most significant factors that contributes to construction waste. ${ }^{10,18,19}$ Design and detail errors often lead to inadequate information required for the buildability

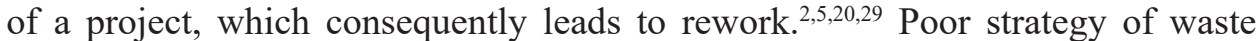
minimisation in Ethiopian building construction sectors was the cause of material wastes. This is consistent with another study by Eze et al. ${ }^{9}$ and Ganim ${ }^{18}$ in which it is indicated as the most significant factor leading to construction wastes. Lack of responsibility on waste management by the resident engineer intended to be the most dominant source of material wastes at every construction site. ${ }^{30}$ 
The current study presented that improper storage of material at the construction sites was the third highest-ranked cause of construction material wastes. Construction material can break and deteriorate due to inadequate or improper storage on the project sites. Material waste caused by inappropriate storage accounted for a large quantities and it is a principal reason for building material wastes. ${ }^{3,9,31}$ As reported by previous studies, wrong material storage is the main problem contributing to construction wastes as an error in storing materials will cause a delay in the project and physical waste generation. ${ }^{2,20}$ It is the main cause of material wastes generated in construction sites. ${ }^{3,32}$ Poor site management was identified as the critical factor causing construction wastes based on the result of this study. Achievement or success in construction projects requires effective site management. ${ }^{33}$ Lack of adequate site management is the influential factor that causes construction wastes. ${ }^{20}$ This implies that appropriate waste management onsite significantly reduces the number of material wastes at construction sites. ${ }^{34}$ On the other hand, poor planning and site supervision were the other dominant factor that causes building construction wastes. According to Adewuyi and Otali ${ }^{8}$, inadequate site supervision is recognised as the influential factor that contributes to material wastes. Appropriate planning and adequate supervision are therefore essential to control the issues that lead to the generation of material wastes. The current study is evidence that errors in the contract documents are indicated as an important factor leading to wastes in construction sites. According to Mbote, Makworo and Kimtai ${ }^{35}$ lack of proper documentation was reported as the major risk factor causing material wastes.

In addition, rework due to worker mistakes holds the seventh position as a source of material wastes in Ethiopia. Construction waste may be generated in different sites if the worker on the project site does not perform their responsibilities effectively and there is an error in the installations that needs rework and replacements. Rework due to errors of site workers reported as a critical factor causing construction wastes. ${ }^{20,32}$ Any mistakes or errors, while the work is in progress, leads to reworks and it is recognised as one of the main sources for the generation of wastes from construction sites. ${ }^{18}$ Moreover, inappropriate construction method was identified and ranked as the eighth-highest influential factor of construction wastes. Research by Luangcharoenrat et al..$^{5}$ report that it is a critical factor that causes material wastes. Furthermore, the analysis result of this study depicts that the arrangement and irregular shapes of the design hold the ninth rank as a cause of construction wastes. If the drawing is not well arranged and its shape is irregular, it is difficult to fit with available standard material dimensions and it needs cutting which leads to wastes. Design complexity and irregularities are the most important factors causing wastage of materials in construction sites. ${ }^{20}$ Finally, the lack of specialised professionals assigned to handle waste issues at 
construction sites has its role as a source of construction wastes. Husnain et al. ${ }^{36}$ states that improper worker's skill is the major influential factor causing wastes of construction materials. Professional inexperience is noted as the main sources of construction wastes in Nigerian construction projects. ${ }^{20}$

\section{CONCLUSION}

The purpose of this paper was to identify the major sources of construction wastes that affect building construction projects in Addis Ababa, Ethiopia. To identify the main sources of construction wastes, a literature review and expert interviews were conducted. A list of 47 factors that causes construction wastes were identified from literature, building construction professionals and categorised into eight major groups. Then, the factors were subjected to further quantitative evaluation in a questionnaire survey. The questionnaire collected from contractors, consultants and clients was analysed and ranked using descriptive mean statistics based on a 5-point Likert scale.

The results of this paper contributed to the study's finding by demonstrating the top influencing factors of construction wastes. The identified critical factors causing construction wastes are frequent design changes, poor waste minimisation strategy, improper material storage, poor site management, poor planning and supervision, contract document error, rework due to worker mistakes, inappropriate construction methods, arrangement and irregular shape of the design and a lack of specialised professionals. The ranking and identification of new and previously reported factors that cause material wastes aids to develop and implement construction waste mitigation strategies. It also allows which aspects must be addressed first to improve waste efficiency and sustainability on construction sites. At every stage of the project, stakeholders involved in building construction projects should address and consider the major influential factors causing material wastes. As this study was carried out in Ethiopia within the context of Addis Ababa building construction projects, further research could be expanded to other regions of the country and construction sectors such as road projects, water work projects and other infrastructure projects. 


\section{REFERENCES}

1. Ajayi, S. O.\& Oyedele, L. O. (2018). Waste-efficient materials procurement for construction projects: A structural equation modelling of critical success factors. Waste Manage., 75, 60-69, https://doi.org/10.1016/j. wasman.2018.01.025.

2. Kaliannan, S., Nagapan, S., Abdullah, A., Sohu, S. \& Jhatial, A. A. (2018). Determining root cause of construction waste generation: A global context. Civ. Eng. J., 4(11), 2539-2547, http://dx.doi.org/10.28991/cej-03091179.

3. Najafpoor, A. A., Zarei, A., Jamali-Behnam, F. Vahedian-Shahroudi, M. \& Zarei, A. (2014). A study identifying causes of construction waste production and applying safety management on construction site. Iranian Journal of Health Sciences, 2(3), 49-54, https://doi.org/10.18869/ acadpub.jhs.2.3.49

4. Zheng, L., Wu, H., Zhang, H., Duan, H., Wang, J., Jiang, W., Dong, B., Liu, G., Zuo, J. \& Song, Q. (2017). Characterizing the generation and flows of construction and demolition waste in China. Constr. Build. Mater., 136, 405-413, http://dx.doi.org/10.1016/j.conbuildmat.2017.01.055.

5. Luangcharoenrat, C., Intrachooto, S., Peansupap, V. \& Sutthinarakorn, W. (2019). Factors influencing construction waste generation in building construction: Thailand's perspective. J. Sustainability, 11(13), 3638, https://doi.org/10.3390/su11133638.

6. Aslam, M. S., Huand, B. and Cui, L. (2020). Review of construction and demolition waste management in China and USA. J. Environ. Manage., 264, 110445, https://doi.org/10.1016/j.jenvman.2020.110445.

7. Rodríguez, G., Bosqueet, IF, S., Asensioal, E., Rojas, MI, S. \& Medina, C. (2020). Construction and demolition waste applications and maximum daily output in Spanish recycling plants. Waste Manage. Res., 38(4), 423432, https://doi.org/10.1177/0734242X20904437.

8. Adewuyi, T. O. \& Otali, M. (2013). Evaluation of causes of construction material waste: Case of rivers state, Nigeria. Ethiopian Journal of Environmental Studies and Management, 6, 746-753, http://dx.doi. org/10.4314/ejesm.v6i6.5S.

9. $\quad$ Eze, E. C., Seghosime, R., Eyong, O. P. \& Loya, O. S. (2016). Assessment of materials waste in the construction industry: A view of construction operatives, tradesmen and artisans in Nigeria. Int. J. Eng. Sci., 6(4), 3247, https://doi.org/10.9790/1813-0604013247.

10. Olusanjo, O. F., Panos, G. \& Ezekiel, C. (2014). Quantitative analysis of the sources of construction waste. J. Constr. Eng., 2014, 651060, http:// dx.doi.org/10.1155/2014/651060. 
11. Enshassi, A., Al-Hallaq, K. \& Mohamed, S. (2006). Causes of contractors' business failure in developing countries: The case of Palestine. J. Constr. Dev. Ctries., 11(2), 1-14. http://hdl.handle.net/20.500.12358/26433.

12. Adewuyi, T.O. \& Odesola, I. A. (2016). Material waste minimization strategies among construction firms in South-South Nigeria. Int. J. Sustain. Constr. Eng. Technol., 7(1), 11-29, https://publisher.uthm.edu.my/ojs/ index.php/IJSCET/article/view/1174.

13. Saidu, I. \& Shakantu, W. (2016). The contributions of construction material waste to project cost overruns in Abuja, Nigeria. Acta Structilia, 23(1), 99-113, https://doi.org/10.18820/24150487/as23i1.4.

14. Endale, T. \& Alula, T. (2017). Assessment of construction waste management and disposal strategies. The case of gelan condomminium construction project site. M. Sc. Thesis, Addis Ababa Science and Technology University, Ethiopia, https://doi.org/10.20372/ nadre: 1548576871.95 .

15. Asmara, S. (2015). Managing and minimizing wastage of construction materials on selected public building projects in Addis Ababa. M. Sc. Thesis, Addis Ababa University, Addis Ababa, Ethiopia, http://etd.aau. edu.et/handle/123456789/5301.

16. Florence, Y. L. \& Mark, C. L. (2014). Implementation of a waste Management plan for construction projects in Singapore. Archit. Sci. Rev., 45(2), 73-81, http://dx.doi.org/10.1080/00038628.2002.9697495.

17. Lingard, H., Graham, P. \& Smithers, G. (2010). Employee perceptions of the solid waste management system operating in a large Australian contracting organization: Implications for company policy implementation. Constr. Manag. Econ., 18(4), 383-393, http://dx.doi. org/10.1080/01446190050024806.

18. Ghanim, A. B. (2014). Study of the causes and m agnitude of wastage of materials on construction sites in Jordan. J. Constr. Eng., 2014, 283298, http://dx.doi.org/10.1155/2014/283298.

19. Ikau, R., Joseph, C. \& Tawie, R. (2016). Factors influencing waste generation in the construction industry in Malaysia. Procedia. Soc. Behav. Sci., 234, 11-18, https://doi.org/10.1016/j.sbspro.2016.10.213.

20. Sunday, D. O. \& Afolarin, A. O. (2013). Causes, effects and remedies of errors in Nigerian construction documents. Organization, Technology and Management in Constructional Journal, 5(1), 676-686, https://doi. org/10.5592/otmcj.2013.1.4. 
21. Polat, G., Damci, A., Turkoglu, H. \& Gurgun, A. P. (2017). Identification of root causes of construction and demolition (C\&D) waste: The case of Turkey. Procedia Eng., 196, 948-955, https://doi.org/10.1016/j. proeng.2017.08.035.

22. Agyekum, K., Ayarkwa, J. \& Adjei-Kumi, T. (2013). Minimizing materials wastage in construction: A lean construction approach. J. Eng. Appl. Sci., 5(1), 444-461.

23. Sasidharani, B. \& Jayanthi, R. (2015). Material waste management in construction industries. Int. J. Sci. Eng. Res., 3(5).

24. Osmani, M. (2013). Design waste mapping: A project life cycle approach. Proceedings of the Institution of Civil Engineers: Waste and resource management, 166(3), 114-127, https://doi.org/10.1680/warm.13.00013.

25. Liu, Z., Osmani, M., Demian, P. \& Baldwin, A. (2015). A BIM-aided construction waste minimisation framework. Autom. Constr., 59, 1-23, http://dx.doi.org/10.1016/j.autcon.2015.07.020.

26. Creswell, J. W. (2013). Qualitative inquiry and research design: Choosing among five approaches. 3rd Ed. Thousand Oaks, CA: Sage.

27. Prabhat, P. \& Meenu, M. (2015). Research Methodology: Tools and Techniques. Romania: Bridge Center.

28. Ajayi, S. O., Oyedele, L. O., Bilal, M., Akinade, O. O., Alaka, A. H. \& Owolabi, H. A. (2017). Critical management practices influencing on-site waste minimization in construction projects. Waste Manage., 59, 330339, http://dx.doi.org/10.1016/j.wasman.2016.10.040.

29. Aiyetan, O. \& Smallwood, J. (2013). Materials management and waste minimisation on construction sites in Lagos state, Nigeria. In EPPM 2013 conference papers. South Carolina: Association of Engineering, Project, and Production Management (EPPM), 1161-1172, https://doi. org/10.32738/CEPPM.201310.0102.

30. Khaleel, T. \& Al-Zubaidy, A. (2017). Major factors contributing to the construction waste generation in building projects of Iraq. MATEC Web Conf., 162, 02034, https://doi.org/10.1051/matecconf/201816202034.

31. Wahab, A. B. \& Lawal, A. F. (2011). An evaluation of waste control measures in construction industry in Nigeria. Afr. J. Environ. Sci. Tech., 5(3), 246-254.

32. Al-Hajj, A. \& Hamani, K. (2011). Material waste in the UAE construction industry: Main causes and minimization practices. Archit. Eng. Des. Manag., 7(4), 221-235, https://doi.org/10.1080/17452007.2011.594576.

33. Mamaru, D. B., Esayas, A. T. \& Sintayehu, A. A. (2017). Investigation of major success factors on building projects management system in Addis Ababa, Ethiopia. Am. J. Civ. Eng., 5(3), 155-163, https://doi. org/10.11648/j.ajce.20170503.15. 
34. Tafesse, S. (2021). Material waste minimization techniques in building construction projects. Ethiopian Journal of Science and Technology, 14(1), 1-19, https://dx.doi.org/10.4314/ejst.v14i1.1.

35. Mbote, R. P., Makworo, M. \& Kimtai, A. K. (2016). An investigation on the influence of factors causing material waste on construction cost of residential building frame. A case of northern region of Nairobi. Int. J. Res. Eng. Technol., 5(9), 436-447.

36. Husnain, A., Muhammad, Q., Muhammad, J. T. \& Hamza, F. G. (2017). Quantification of material wastage in construction industry of Pakistan: An analytical relationship between building types and waste generation. J. Constr. Dev. Ctries., 22(2), 19-34, https://doi.org/10.21315/ jcdc2017.22.2.2. 